\title{
ВИЗНАННЯ ТА ВИКОНАННЯ \\ ІНОЗЕМНОГО СУДОВОГО РІШЕННЯ: \\ ТЕОРЕТИЧНІ І ПРАКТИЧНІ АСПЕКТИ
}

Белікова С. O.

\section{ВСТУП}

Питання щодо визнання та виконання судових рішень іноземних держав в Україні сьогодні не втрачає своєї актуальності. Необхідність визнання та виконання судового рішення іноземної держави пов'язана зі здійсненням захисту права фізичної та юридичної особи на підставі відповідного рішення на території України.

Сьогодні чинне національне законодавство не надає правового визначення понять «визнання» та «виконання» рішення іноземного суду, унаслідок чого в науковій спільності постійно точаться дискусії із цього приводу.

Незважаючи на тривалі дискусії, у науковій доктрині існує декілька підходів до змісту понять «визнання» та «виконання» рішень іноземних судів. Такі наукові підходи варто кваліфікувати за певними категоріями, а саме: 1) за категорією юридичної сили (Н.I. Маришева, А.І. Муранов, С.Я. Фурса, М.Й. Штефан та інші); 2) за категорією правової дії та законної сили (Л.П. Ануфрієва, Т.Я. Фортуна й інші); 3) за категорією цивільних прав та обов'язків (М.М. Богуславський, Л.В. Чубарєв та інші).

Так, Н.I. Маришева пропонує таке розуміння: «визнання рішень судів іншої держави означає надання їм такої юридичної сили, яку мають рішення судів цієї держави, що набрали законної сили: вони набувають властивостей незаперечності, винятковості, а рішення про присудження - також виконуваності» ${ }^{1}$.

Дослідник-процесуаліст С.Я. Фурса в науково-практичному коментарі до Цивільного процесуального кодексу України зазначає, що «під визнанням слід розуміти надання рішенню такої самої юридичної сили, яку має рішення, постановлене судом України, після набрання ним законної сили»².

На думку М.Й. Штефана, «визнання - це надання юрисдикційному акту іноземної держави сили і значення рішення вітчизняного суду, яке

\footnotetext{
1 Лев М.О. До питання розуміння визнання іноземного судового рішення в міжнародному приватному праві. Часопис Київського університету права. 2013. № 2. С. 379.

2 Там само. С. 380. 
не вимагає застосування примусових заходів на захист і поновлення порушеного права» ${ }^{3}$.

Протилежне бачення має A.I. Муранов, який уважає, що «до моменту приведення іноземного рішення до виконання жодною примусовою силою воно не володіє і не наділяє сторони якиминебудь беззаперечними правами та обов'язками. Тобто, до визнання іноземного судового рішення вітчизняне право не визнає за ним юридичної сили» ${ }^{4}$.

Через категорії законної сили судового рішення, на наш погляд, вдало надають визначення цих понять Л.П. Ануфрієва й Т.Я. Фортуна.

Так, Л.П. Ануфрієва зазначає: «Признание решений иностранного суда - придание им такой же юридической силы, которую имеют вступившие в законную силу решения судов данного государства: свойства неопровержимости, исключительности; а решения о присуждении также исполнимости; они обязательны для должностных лиц и органов данного государства» ${ }^{5}$.

Т.Я. Фортуна чіткіше дає наукове визначення поняття «визнання рішення іноземного судового рішення», яке, на його погляд, варто розуміти як «поширення законної сили, неспростовності, виключності рішення іноземного суду на територію держави, яка визнає це рішення», а під виконанням рішення іноземного суду - «застосування засобів примусового виконання рішення іноземного суду в порядку, визначеному законодавством держави, на території якої виконується іноземне рішення» ${ }^{6}$.

За категорією цивільних прав та обов'язків, на думку M.M. Богуславського, «визнання рішення іноземного суду означає, що воно слугує підтвердженням цивільних прав та обов'язків тією ж мірою, що й рішення вітчизняного суду» ${ }^{7}$. Аналогічне твердження має й Л.В. Чубарєв: «... визнання іноземного судового рішення як підтвердження певних цивільних прав і обов’язків у тому самому розумінні як рішення власного суду» ${ }^{8}$.

\footnotetext{
3 Лев М.О. До питання розуміння визнання іноземного судового рішення в міжнародному приватному праві. Часопис Київського університету права. 2013. № 2. С. 380.

4 Там само. С. 379.

5 Богуславский М.М. Международное частное право : учебник. Москва, 2004. С. 378.

6 Фортуна Т.Я. Поняття та правова природа визнання та виконання рішень іноземних судів в Україні. Адвокат. 2011. № 7 (130). С. 43.

7 Богуславский М.М. Международное частное право : учебник. Москва, 2004. С. 379.

8 Там само. С. 380.
} 
Під іншим змістом виражає це поняття М.О. Лев, акцентуючи увагу на тому, що «визнання іноземного судового рішення являє собою юридичний акт, яким суверенна держава, поширюючи дію іноземного рішення на власну територію, висловлює своє ставлення до нього як до юридичного факту, з яким пов'язується виникнення, зміна або припинення встановлених іноземним судом беззаперечних правовідносин» ${ }^{9}$.

Ураховуючи думки науковців, на наш погляд, під визнанням рішення іноземного суду необхідно розуміти поширення законної сили рішення іноземного суду на територію України в порядку, установленому законодавством України, а під виконанням рішення іноземного суду розуміється застосування всіх засобів щодо примусового виконання рішення іноземного суду в порядку, визначеному законодавством держави, на території якої воно виконується.

Отже, поняття «визнання» та «виконання» рішення іноземного суду є взаємопов' язаними, оскільки визнання іноземного судового рішення $\epsilon$ правовою підставою для його звернення до примусового виконання на території України. Хоча є певна категорія справ, які не підлягають примусовому виконанню, але, відповідно до процесуального законодавства, потребують їх визнання, зокрема це рішення про розірвання шлюбу, позбавлення батьківських прав, оголошення особи померлою, 3 питань банкрутства тощо.

\section{1. Правова природа і правове регулювання визнання та виконання рішень іноземних судів}

Поняття «визнання» та «виконання» рішень іноземних судів у незалежній Україні на законодавчому рівні вперше визначено в ст. 1 Закону України «Про визнання та виконання в Україні рішень іноземних судів» від 29 листопада 2001 року № 2860-III ${ }^{10}$, який згодом утратив чинність на підставі Закону України «Про внесення змін та визнання такими, що втратили чинність, деяких законодавчих актів України» від 6 вересня 2005 року № 2798-IV. Трактування цих понять зводилося до того, що під визнанням рішення іноземного суду розумілося поширення законної сили рішення іноземного суду на територію України в порядку, установленому цим законом, а під виконанням рішення іноземного суду - застосування засобів

\footnotetext{
9 Богуславский М.М. Международное частное право : учебник. Москва, 2004. С. 380.

10 Про визнання та виконання в Україні рішень іноземних судів : Закон України від 29 листопада 2001 року № 2860-III. URL: https://zakon.rada.gov.ua/laws/show/2860-14.
} 
примусового виконання рішення іноземного суду в Україні в порядку, передбаченому законом ${ }^{11}$.

Надалі в Цивільному процесуальному кодексі України від 18 березня 2004 року № 1618-IV (далі - ЦПК України) (що набув чинності 1 вересня 2005 року) законодавець передбачив цілий розділ IX, присвячений визнанню та виконанню рішень іноземних судів, міжнародних комерційних арбітражів в Україні, наданню дозволу на примусове виконання рішень третейських судів ${ }^{12}$. Питання щодо визнання та виконання рішень іноземних судів/арбітражних рішень також визначені в Законах України «Про міжнародне приватне право» від 23 червня 2005 року № 2709-IV ${ }^{13}$ та «Про міжнародний комерційний арбітраж» від 24 лютого 1994 року № 4002-XII ${ }^{14}$. Процедура виконання судових рішень на території України регламентована базовим Законом України «Про виконавче провадження» ${ }^{15}$, а також іншими нормативно-правовими актами 3 виконавчого провадження.

Статтею 9 Конституції України ${ }^{16}$ передбачено, що чинні міжнародні договори, згода на обов'язковість яких надана Верховною Радою України, є частиною національного законодавства України.

Відповідно до ч. 1 ст. 462 ЦПК України, рішення іноземного суду (суду іноземної держави; інших компетентних органів іноземних держав, до компетенції яких належить розгляд цивільних справ) визнається та виконується в Україні, якщо їх визнання та виконання передбачено міжнародним договором, згода на обов'язковість якого надана Верховною Радою України, або за принципом взаємності.

Підставою для визнання в Україні рішення іноземного суду є звернення стягувача до суду цивільної юрисдикції з відповідним клопотанням за місцем проживання (перебування) або місцезнаходженням боржника. Отже, клопотання є основним процесуальним документом,

11 Про визнання та виконання в Україні рішень іноземних судів : Закон України від 29 листопада 2001 року № 2860-III. URL: https://zakon.rada.gov.ua/laws/show/2860-14.

12 Цивільний процесуальний кодекс України від 18 березня 2004 року № 1618-IV. URL: https://zakon.rada.gov.ua/laws/show/1618-15.

13 Про міжнародне приватне право : Закон України від 23 червня 2005 року № 2709-IV. URL: https://zakon.rada.gov.ua/laws/show/2709-15.

14 Про міжнародний комерційний арбітраж: Закон України від 24 лютого 1994 року № 4002-XII. URL: https://zakon.rada.gov.ua/laws/show/4002-12.

15 Про виконавче провадження : Закон України від 2 червня 2016 року № 1404-VIII. URL: https://zakon.rada.gov.ua/laws/show/1404-19.

16 Конституція України від 28 червня 1996 року. URL: https://zakon.rada.gov.ua/laws/ show/254к/96-вр. 
який надає право фізичній чи юридичній особі отримати дозвіл на примусове виконання рішення іноземного суду.

Правове регулювання порядку розгляду зазначеного клопотання, окрім процесуального законодавства, здійснюється нормами європейської Конвенції «Про визнання та приведення до виконання іноземних арбітражних рішень» від 10 червня 1958 року $^{17}$, багатосторонньої угоди «Про порядок вирішення спорів, пов’ язаних із здійсненням господарської діяльності», ратифікованої 19 грудня 1992 року та підписаною Україною 20 березня 1992 року ${ }^{18}$, Конвенції «Про правову допомогу і правові відносини у цивільних, сімейних і кримінальних справах», ратифікованої 10 листопада 1994 року та підписаної Україною 22 січня 1995 року $^{19}$, іншими нормативно-правовими актами України.

Так, у ст. 51 Конвенції «Про правову допомогу і правові відносини у цивільних, сімейних і кримінальних справах» наведено перелік рішень, винесених на території інших держав, які визнаються та виконуються в Україні, а саме: 1) рішення установ юстиції по цивільних і сімейних справах, включаючи затверджені судом мирові угоди по таких справах і нотаріальні акти щодо грошових зобов'язань; 2) рішення судів по кримінальних справах про відшкодування збитків.

Надалі цей перелік уніфіковано в ст. 81 Закону України «Про міжнародне приватне право», згідно з якою в Україні можуть бути визнані та виконані рішення іноземних судів у справах, що виникають із цивільних, трудових, сімейних і господарських правовідносин, вироки іноземних судів у кримінальних провадженнях у частині, що стосується відшкодування шкоди та заподіяних збитків, а також рішення іноземних арбітражів та інших органів іноземних держав, до компетенції яких належить розгляд цивільних і господарських справ, що набрали законної сили.

Питанням визнання й виконання іноземних судових рішень в Україні приділено увагу в Інструкції «Про порядок виконання міжнародних договорів 3 питань надання правової допомоги в цивільних справах щодо вручення, отримання доказів та визнання і виконання судових рішень», затвердженої Наказом Міністерства юстиції

17 Про визнання та приведення до виконання іноземних арбітражних рішень : Конвенція від 10 червня 1958 року. URL: https://zakon.rada.gov.ua/laws/show/995_070.

18 Про порядок вирішення спорів, пов'язаних із здійсненням господарської діяльності : Угода від 19 грудня 1992 року. URL: https://zakon.rada.gov.ua/laws/show/997_076.

19 Про правову допомогу і правові відносини у цивільних, сімейних і кримінальних справах : Конвенція від 1993 року. URL: https://zakon.rada.gov.ua/laws/show/997_009. 
України від 27 червня 2008 року № 1092/5/5420 (зареєстрованого в Міністерстві юстиції України 2 липня 2008 року за № 573/15264). Ії̈ правові норми регламентують, що рішення іноземного суду визнається та виконується в Україні, якщо його визнання та виконання передбачене міжнародним договором країни або за принципом взаємності у відносинах з іноземною державою, рішення суду якої має виконуватися в Україні.

Водночас, на наш погляд, існують певні передумови для звернення до національного суду з клопотанням про надання дозволу на примусове виконання рішення іноземного суду. Вони полягають у такому:

1. Наявність цивільної правоздатності й дієздатності фізичної та юридичної особи.

Так, відповідно до ст.ст. 17, 18, 26 Закону України «Про міжнародне приватне право» (далі - Закон (для цього розділу)), цивільна правоздатність і дієздатність фізичної та юридичної особи визначаються їхнім особистим законом.

Іноземні особи: іноземці, особи без громадянства, іноземні юридичні особи, іноземні держави (їхні органи та посадові особи) та міжнародні організації мають право звертатися до судів України для захисту своїх прав, свобод чи інтересів. Процесуальна правоздатність і дієздатність іноземних осіб в Україні визначаються відповідно до права України (ч. 1 ст. 73, ч. 1 ст. 74 Закону).

Утім, згідно з ч. 2 ст. 74 Закону України «Про міжнародне приватне право», суд може витребувати в іноземній юридичній особі документ, що є доказом ії правосуб'єктності (сертифікат реєстрації, витяг із торгового реєстру тощо), який, відповідно до ст. 13 цього Закону, визнається дійсним в Україні в разі його легалізації.

Наявність цивільної правоздатності й дієздатності надає фізичній і юридичній особам право звернутися до судів України з відповідним клопотання про примусове виконання рішення іноземного суду.

2. Підсудність судам України справ щодо іноземних осіб.

Підстави для визначення підсудності справ судам України наведені в ст. 76 Закону, згідно з якою суди можуть приймати до свого провадження й розглядати будь-які справи щодо іноземної особи, якщо на території України відповідач у справі має місце проживання або місцезнаходження або рухоме чи нерухоме майно, на яке можна накласти

\footnotetext{
20 Про затвердження Інструкції про порядок виконання міжнародних договорів 3 питань надання правової допомоги в цивільних справах щодо вручення документів, отримання доказів та визнання і виконання судових рішень : Наказ Міністерства юстиції України від 27 червня 2008 року № 1092/5/54. URL: https://zakon.rada.gov.ua/laws/show/z0573-08.
} 
стягнення, або знаходиться філія чи представництво іноземної юридичної особи-відповідача.

Окрім загальних правил визначення підсудності справ, в Україні не можуть бути визнані та підлягати виконанню рішення іноземних судів у справах окремої категорії. Це справи зі стягнення заборгованості з підприємств оборонно-промислового комплексу, унесеного до переліку об'єктів державної власності, що мають стратегічне значення для економіки й безпеки держави, а також стягнення заборгованості на користь інших юридичних осіб, указаних у ч. 2 ст. 81 Закону.

3. Зарахування справи до цивільної юрисдикції України.

Процесуальні питання, пов'язані з визнанням і виконанням рішень іноземних судів, до компетенції яких належить розгляд цивільних справ, а також рішень міжнародного комерційного арбітражу, урегульовані розділом IX ЦПК України (ст.ст. 462-481 ЦПК України) за умови, якщо їх визнання та виконання передбачено міжнародним договором, згода на обов'язковість якого надана Верховною Радою України, або за принципом взаємності. Винятком $є$ вирок іноземного суду в кримінальному провадженні (справі) та інші документи цього провадження, які визнаються й виконуються за правилами кримінального процесуального законодавства України.

4. Набуття рішенням іноземного суду законної сили.

Рішення іноземного суду підлягає його визнанню та виконанню на території України лише в тому разі, якщо воно набрало законної сили за результатом розгляду справи судом іноземної держави. Якщо рішення іноземного суду за законодавством держави, на території якого воно постановлено, не набрало законної сили, то в разі звернення такого рішення до виконання в Україні національний суд зобов'язаний винести ухвалу й відмовити в задоволенні клопотання про надання дозволу на виконання зазначеного рішення, як це передбачено п. 1 ч. 2 ст. 468 ЦПК України. Винятком є лише ті випадки, коли рішення підлягає виконанню до набрання ним законної сили.

5. Пред'явлення іноземною особою рішення іноземного суду до примусового виконання протягом установленого законодавством строку.

Як передбачено ст. 463 ЦПК України, рішення іноземного суду може бути пред'явлено до примусового виконання в Україні протягом трьох років з дня набрання ним законної сили, за винятком рішення про стягнення періодичних платежів, яке може бути пред’явлено до 
примусового виконання протягом усього строку проведення стягнення з погашенням заборгованості за останні три роки.

Пропущення особою (іiі представником) строку для пред'явлення до примусового виконання зазначеного рішення на території України $€$ законною підставою для відмови судом у його задоволенні.

Отже, недотримання іноземною особою перелічених умов позбавляє їі права звернення до юрисдикційного суду України з вимогою щодо визнання та виконання іноземного судового рішення.

\section{2. Порядок визнання та виконання рішень іноземних судів}

Якщо рішення іноземного суду не виконано боржником у добровільному порядку, то стягувач вправі звернутися до суду України з клопотанням про примусове виконання цього рішення. Процедура визнання та виконання рішень іноземних судів передбачена ЦПК України, Законом України «Про виконавче провадження», іншими нормативно-правовими актами.

Свропейська конвенція «Про правову допомогу і правові відносини в цивільних, сімейних і кримінальних справах» визначає загальний підхід до розгляду клопотання про примусове виконання рішень іноземних судів. Правові норми ст. 53 цієї Конвенції трактують, що клопотання про вирішення примусового виконання рішення подається в компетентний суд сторони, що домовляється, де рішення підлягає виконанню. Воно також може бути подано до суду, який виніс рішення у справі в першій інстанції. Цей суд направляє клопотання суду, компетентному винести рішення по клопотанню.

Національне законодавство дещо деталізує процесуальний порядок визнання та виконання такого роду рішень.

Так, питання про надання дозволу на примусове виконання рішення іноземного суду розглядається судом за місцем проживання (перебування) або місцезнаходженням боржника. Якщо боржник не має місця проживання (перебування) чи місцезнаходження на території України або його місце проживання (перебування), так само як і місцезнаходження, невідомо, то, згідно зі ст. 464 ЦПК України, таке питання розглядається судом за місцезнаходженням в Україні його майна.

Відповідно до п. 5.2 Інструкції «Про порядок виконання міжнародних договорів з питань надання правової допомоги в цивільних справах щодо вручення, отримання доказів та визнання і виконання судових рішень» (далі - Інструкція), клопотання заінтересованої особи про 
визнання й виконання рішення іноземного суду чи іншого компетентного органу подається безпосередньо до суду України.

Водночас нормами ЦПК України та Інструкції врегульовано подання такого клопотання до суду через органи державної влади України, але в тому випадку, якщо це передбачено міжнародним договором України. У такому разі іноземний суд, який розглянув справу й ухвалив рішення в першій інстанції, надсилає клопотання на розгляд компетентного суду України через Міністерство юстиції України (далі - Мін'юст).

Згідно з п. 5.4 Інструкції, Мін'юст, отримавши іноземне клопотання, перевіряє наявність і чинність міжнародного договору України у відносинах із запитуючою державою, а також наявність документів, необхідних, відповідно до міжнародного договору, для визнання та виконання рішення іноземного суду в Україні.

Якщо клопотання відповідає міжнародному договору України, Мін'юст через головне територіальне управління юстиції направляє іноземне клопотання до суду України за місцем проживання (перебування) або місцезнаходженням боржника чи його майна.

Національне процесуальне законодавство передбачає розгляд такого клопотання суддею одноосібно у відкритому судовому засіданні. Неявка без поважних причин у судове засідання будь-якої зі сторін або їхніх представників, стосовно яких суду відомо про своєчасне вручення повістки про виклик до суду, не $є$ перешкодою для розгляду клопотання, якщо будь-якою зі сторін не порушено питання про перенесення його розгляду (ч. ч. 4, 5 ст. 467 ЦПК України). Ця правова норма цілком підтверджує безперешкодний доступ до правосуддя іноземної особи та іiі участі в розгляді клопотання, якщо воно відповідає закону.

Наприклад, під час розгляду Луцьким міськрайонним судом справи про позбавлення батьківських прав боржник у судове засідання не з'являвся, будучи належним чином повідомленим про час і місце іiі розгляду. Ураховуючи наявність договору «Про дружбу і співробітництво між Італійською Республікою та Україною» від 3 травня 1995 року, ратифікованого Верховною Радою України 26 квітня 1996 року, дотримання форми і змісту клопотання стягувача й обставини справи, суд в ухвалі від 7 жовтня 2019 року дійшов висновку, що рішення Суду у справах неповнолітніх міста Неаполь Республіки Італія від 23 січня 2014 року підлягає виконанню на території України ${ }^{21}$.

\footnotetext{
21 Ухвала Луцького міськрайонного суду від 7 жовтня 2019 року у справі № 161/11010/19. URL: http://reyestr.court.gov.ua/Review/85620463.
} 
Передусім іноземне клопотання за своєю формою та змістом обов'язково має відповідати вимогам ст. 466 ЦПК України. Наслідком недотримання іноземною особою встановлених національним законодавством вимог є залишення судом без розгляду такого клопотання.

Так, клопотання подається в письмовій формі й має містити таке: 1) ім'я (найменування) особи, що подає клопотання, зазначення ії місця проживання (перебування) або місцезнаходження; 2) ім'я (найменування) боржника, зазначення його місця проживання (перебування), його місцезнаходження чи місцезнаходження його майна в Україні; 3) мотиви подання клопотання.

До вказаного клопотання водночас додаються документи, передбачені міжнародними договорами, згода на обов'язковість яких надана Верховною Радою України. Якщо міжнародними договорами, згода на обов'язковість яких надана Верховною Радою України, не визначено перелік документів, що мають додаватися до клопотання, або за відсутності такого договору, до нього необхідно долучити: 1) засвідчену в установленому порядку копію рішення іноземного суду; 2) офіційний документ про те, що рішення іноземного суду набрало законної сили (якщо це не зазначено в самому рішенні); 3 ) документ, який засвідчує, що сторона, стосовно якої постановлено рішення іноземного суду та яка не брала участі в судовому процесі, була належним чином повідомлена про дату, час і місце розгляду справи; 4) документ, що визначає, у якій частині чи з якого часу рішення іноземного суду підлягає виконанню (якщо воно вже виконувалося раніше); 5) документ, що посвідчує повноваження представника (якщо клопотання подається представником); 6) засвідчений відповідно до законодавства переклад перелічених документів українською мовою або мовою, передбаченою міжнародними договорами України.

Наприклад, рішенням Мукачівського міськрайонного суду від 6 грудня 2019 року задоволено клопотання стягувача про надання дозволу на примусове виконання рішення іноземного суду по справі про стягнення аліментів. Оскільки це клопотання відповідає всім вимогам процесуального законодавства, суд надав дозвіл на примусове виконання рішення районного суду в Чеському Крумлові Чеської Республіки від 23 квітня 2013 року і стягнув з боржника аліменти на утримання 4-х неповнолітніх дітей ${ }^{22}$.

22 Ухвала Мукачівського міськрайонного суду від 6 грудня 2019 року у справі № 2-к/303/1/19. URL: http://reyestr.court.gov.ua/Review/86157182. 
Наступний приклад: в ухвалі Драбівського районного суду Черкаської області від 4 листопада 2019 року зазначено, що, згідно 3 довідкою, виданою судом Октябрського району міста Гродно Республіки Білорусь, рішення суду від 24 серпня 2018 року про стягнення з боржника на користь стягувача грошової суми набрало законної сили 11 вересня 2018 року, на території Республіки Білорусь не виконувалося та підлягає виконанню ${ }^{23}$.

Отже, у разі відповідності клопотання процесуальному законодавству суди задовольняють вимоги, викладені в клопотанні, постановляючи позитивні рішення. Недотримання іноземною особою вищенаведених процесуальних вимог щодо складання клопотання та долучення до нього всіх необхідних документів може стати об'єктивною підставою для залишення його без розгляду, оскільки буде відсутній предмет судового спору.

Цілком логічним є твердження в п. 12 Постанови Пленуму Верховного Суду України «Про практику розгляду судами клопотань про визнання виконання рішень іноземних судів та арбітражі і про скасування рішень, постановлених у порядку міжнародного комерційного арбітражу на території України» ${ }^{24}$ від 24 грудня 1999 року № 12, що клопотання про визнання й виконання рішень іноземних судів (арбітражів) суд розглядає у визначених ними межах і не може входити в обговорення правильності цих рішень по суті, вносити до останніх будь-які зміни.

На наш погляд, таке твердження судового органу є безумовно тактовним, оскільки мова йде не про відповідність винесеного рішення іноземним судом законодавству іноземної держави, матеріалам справи або предмету спору, а лише про визнання його на території іншої держави (України) та допущення його до виконання. У цьому разі винятком є питання стосовно переведення іноземної валюти в національну валюту. Із цього приводу цивільне процесуальне законодавство України надає чітке роз'яснення для суду, який розглядає клопотання іноземної особи.

Так, згідно з ч. 8 ст. 467 ЦПК України, якщо в рішенні іноземного суду суму стягнення зазначено в іноземній валюті, то суд визначає

23 Ухвала Драбівського районного суду Черкаської області від 4 листопада 2019 року у справі № 692/850/19. URL: http://reyestr.court.gov.ua/Review/85443692.

24 Про практику розгляду судами клопотань про визнання виконання рішень іноземних судів та арбітражі і про скасування рішень, постановлених у порядку міжнародного комерційного арбітражу на території України : Постанова Пленуму Верховного Суду України від 24 грудня 1999 року № 12. URL: https://zakon.rada.gov.ua/laws/show/v0012700-99. 
суму в національній валюті за курсом Національного банку України на день постановлення ухвали.

Звертаючись до питання примусового виконання рішень іноземних судів, варто зазначити, що спеціальне законодавство - Закон України «Про виконавче провадження» (далі - Закон (для цього розділу)) фактично не містить правових норм «прямої дії», які б регулювали саме виконання рішень цієї категорії. Тому незайвим було б уніфікувати процесуальне законодавство із законодавством про виконавче провадження, виокремивши в Законі окремий розділ, присвячений примусовому виконанню рішень іноземних судів. Такий підхід лише сприятиме дотриманню чіткої процедури з виконання рішень цієї категорії з боку як органів примусового виконання, так і сторін виконавчого провадження, а також дасть змогу уникнути правових прогалин у національному законодавстві.

Зокрема, у п. 1 ч. 1 ст. 3 Закону зазначено, що примусовому виконанню підлягають виконавчі документи, у тому числі видані на підставі рішень іноземних судів.

Подальше примусове виконання таких рішень відбувається в загальному порядку.

Отже, після визнання національним судом цивільної юрисдикції рішення іноземного суду він надає дозвіл на примусове виконання цього рішення шляхом винесення ухвали. Звернення такого рішення до примусового виконання відбувається після видачі національним судом виконавчого листа, який уноситься державним виконавцем до Сдиного державного реєстру виконавчих документів.

За загальним правилом, місцем виконання рішення іноземного суду $\epsilon$ місце проживання, перебування, роботи боржника або за місцезнаходженням його майна.

Так, згідно з ч. 1 ст. 24 Закону, виконавчі дії провадяться державним виконавцем за місцем проживання, перебування, роботи боржника або за місцезнаходженням його майна. Право вибору місця відкриття виконавчого провадження між кількома органами державної виконавчої служби, що можуть учиняти виконавчі дії щодо виконання рішення на території, на яку поширюються їхні функції, належить стягувачу.

Однак варто наголосити на тому, що не всі рішення іноземних судів підлягають примусовому виконанню. Законодавець передбачив окрему категорію рішень, які не підлягають примусовому виконанню, і порядку їх виконанню присвячена глава 2 розділу IX ЦПК України. 
Зокрема, це рішення стосовно шлюбних відносин, позбавлення батьківських прав, усиновлення дитини, соціального забезпечення, спадкування та правонаступництва, банкрутства чи ліквідації неплатоспроможних юридичних осіб тощо.

Наприклад, ухвалою Херсонського міського суду Херсонської області від 5 грудня 2019 року у справі № 766/10821/19 задоволено клопотання іноземної особи про визнання рішення іноземного суду, що не підлягає примусовому виконанню, і визнано на території України рішення однопредставного суду першої інстанції м. Афіни (Греція) від 9 липня 2018 року у справі № 1839/2018, відповідно до якого проголошено усиновленою дитиною повнолітнього, який народився в м. Херсон, Україна ${ }^{25}$.

\section{3. Проблемні питання, які виникають під час розгляду справ про визнання судових рішень іноземних держав і їх виконанні}

З метою вдосконалення правозастосовної практики та ефективності виконання рішень іноземних судів доцільно проаналізувати практику розгляду національними судами цивільної юрисдикції справ з іноземним елементом.

Проведений аналіз судової практики дав можливість дійти висновку, що під час розгляду судами України справ щодо визнання рішень іноземних судів на території України та звернення до їх виконання виникає чимало проблемних питань процесуального характеру. На деякі з них варто звернути увагу.

1. Ненадання суду заявником доказів щодо набрання рішенням іноземного суду законної сили.

Процесуальне законодавство передбачає доведення кожною стороною у справі тих обставин, на які вона посилається як на підставу своїх вимог або заперечень. Ці обставини мають бути підтверджені належними, допустимими, достовірними й достатніми доказами. У разі ненадання таких доказів суд може визнати обставину невчинення відповідних дій або відсутності події встановленою (ст.ст. 77-81 ЦПК України).

До клопотання про надання дозволу на примусове виконання рішення іноземного суду заявник зобов'язаний надати суду України офіційний документ, який підтверджує, що вказане рішення набрало законної сили (якщо це не зазначено в самому рішенні). Наслідком

\footnotetext{
25 Ухвала Херсонського міського суду Херсонської області від 5грудня 2019 року у справі № 766/10821/19. URL: http://reyestr.court.gov.ua/Review/86137588.
} 
ненадання такого документа є залишення судом без розгляду клопотання, як це передбачено ч. 4 ст. 466 ЦПК України.

Так, Київський апеляційний суд постановою від 3 грудня 2019 року у справі № 372/2267/19²6 за апеляційною скаргою Глобал Трейдинг ГмбХ скасував ухвалу суду першої інстанції, а клопотання Глобал Трейдинг ГмбХ про надання дозволу на примусове виконання рішення іноземного суду направив до цього суду для продовження розгляду. Підставою для скасування рішення цивільної юрисдикції стало те, що стягувач не долучив до свого клопотання листа Земельного суду Мьонхенгладбаха від 30 жовтня 2019 року, що рішення іноземного суду має законну силу. Суд апеляційної інстанції дійшов висновку, що вказаний документ не був поданий до суду першої інстанції, тому, відповідно, він не був предметом його оцінки.

2. Надання іноземною особою до суду неоформлених належним чином документів.

Законодавець у ст. 466 ЦПК України навів чіткий перелік документів, які мають бути долучені до клопотання, а також передбачив вимоги щодо їх процесуального оформлення. Якщо суд установив, що клопотання й долучені до нього документи не оформлено відповідно до вимог процесуального законодавства, залишає його без розгляду та повертає клопотання разом з усіма документами особі, яка його подала.

Ухвалою Жовтневого районного суду м. Харкова від 4 листопада 2019 року у справі № 639/7923/1927 клопотання іноземної особи залишено без розгляду, оскільки заявником додано до нього ксерокопії документів, засвідчених лише підписом заявника.

Проблемним залишається питання щодо недолучення стягувачем до поданого ним клопотання засвідченого відповідно до законодавства перекладу документів українською мовою або мовою, передбаченою міжнародними договорами (наприклад, ухвала від 8 листопада 2019 року Фастівського міськрайонного суду Київської області у справі № 2-к/381/1/19²).

3. Пропущення трирічного строку звернення до суду з клопотанням про надання дозволу на примусове виконання рішення іноземного суду.

\footnotetext{
26 Постанова Київського апеляційного суду від 3 грудня 2019 року у справі № 372/2267/19. URL: http://reyestr.court.gov.ua/Review/86203863.

27 Ухвала Жовтневого районного суду м. Харкова від 4 листопада 2019 року у справі № 639/7923/19. URL: http://reyestr.court.gov.ua/Review/85697736.

28 Ухвала Фастівського міськрайонного суду Київської області від 8 листопада 2019 року у справі № 2-к/381/1/19. URL: http://reyestr.court.gov.ua/Review/85510320.
} 
Конвенція «Про правову допомогу і правові відносини у цивільних, сімейних і кримінальних справах» (п. «е» ст. 55), яка регулює порядок надання правової допомоги між державами-членами Співдружності Незалежних Держав зазначає, що у видачі дозволу на примусове виконання може бути відмовлено у випадках, якщо минув термін давності примусового виконання, передбачений законодавством Договірної Сторони, суд якої виконує доручення.

Для звернення до суду цивільної юрисдикції з клопотанням установлений трирічний строк, визначений ст. 463 ЦПК України. Отже, у разі порушення цього строку суди, відповідно до п. 5 ч. 2 ст. 468 ЦПК України, можуть відмовити в задоволенні цього клопотання.

Ухвалою від 8 листопада 2019 року Фастівський міськрайонний суд Київської області у справі 2-к/381/1/19 відмовив у задоволенні клопотання Відкритого акціонерного товариства «Нафтан» про надання дозволу на примусове виконання рішення економічного суду Вітебської області про стягнення на його користь 3 ТОВ «Науково виробниче об'єднання Фастівський завод хімічного машинобудування «Червоний Жовтень» відповідної суми коштів. Причиною відмови стало пропущення стягувачем строків звернення до суду про надання дозволу на примусове виконання, оскільки рішення економічного суду Вітебської області від 17 вересня 2015 року вступило в законну силу 18 листопада 2015 року, а клопотання про його визнання та примусове виконання подане поза межами трирічного строку - 5 червня 2019 року.

3. Звернення $з$ клопотанням до суду за місцем знаходження боржника.

Статтею 93 Цивільного кодексу України ${ }^{29}$ чітко визначено, що місцезнаходженням юридичної особи є фактичне місце ведення діяльності чи розташування офісу, з якого проводиться щоденне керування діяльністю юридичною особою (переважно знаходиться керівництво) та здійснення управління й обліку.

Питання про надання дозволу на примусове виконання рішення іноземного суду розглядається судом за місцем проживання (перебування) або місцезнаходженням боржника, як це передбачено ч. 1 ст. 464 ЦПК України, п. 5.3 Інструкції «Про порядок виконання міжнародних договорів з питань надання правової допомоги в цивільних справах щодо вручення, отримання доказів та визнання і виконання судових рішень».

\footnotetext{
29 Цивільний кодекс України від 16 січня 2003 року. URL: https://zakon.rada.gov.ua/laws/ show/435-15.
} 
Рішенням Орджонікідзевського районного суду м. Запоріжжя від 25 листопада 2019 року у справі № 335/8518/17 2-к/335/5/201930 залишено судом без розгляду та повернуто заявнику клопотання ТОВ «Квадро Систем» про визнання на території України рішення Міжнародного комерційного арбітражного суду при Асоціації міжнародних правових досліджень від 7 червня 2017 року щодо визнання за ним права розпорядження товаром.

Як убачається з матеріалів справи, зокрема копії статуту боржника, у цій справі його місцезнаходженням є Естонська Республіка, Тіллін, Хар'юрський повіт. У матеріалах справи відсутні дані, що місцезнаходження боржника є іншим. Отже, доказу того, що боржник проживає (перебуває) або знаходиться на території Орджонікідзевського районного суду м. Запоріжжя, матеріали цивільної справи не містять.

Вищенаведений приклад судової практики ще раз підтверджує необхідність дотримання іноземною особою або його представником вимог національного процесуального законодавства в разі звернення до судів України з клопотанням про надання дозволу на примусове виконання рішення іноземного суду. Недотримання стягувачем вимог законодавства може бути наслідком пропущення строку давності для рішення іноземного суду та неможливістю його подальшого виконання.

\section{ВИСНОВКИ}

Необхідність визнання та виконання рішень іноземних судів пов'язано зі здійсненням захисту права фізичної та юридичної особи на території України, підтвердженого відповідним рішенням.

Визнання та виконання іноземного судового рішення регулюється національним законодавством України, зокрема нормами ЦПК України, а також міжнародними договорами, а процедура виконання таких рішень - законодавством про виконавче провадження.

Визнання іноземного судового рішення національними судами $є$ необхідною передумовою його подальшого виконання. Проте під час розгляду судами справ, порушених за клопотаннями іноземних осіб, виникає низка проблемних питань, без з'ясування яких неможливо сподіватися на його ефективне виконання. Прикладом цього твердження є недотримання заявником принципу підсудності, надання ним до суду неоформлених належним чином документів, порушення строків давності.

30 Ухвала Орджонікідзевського районного суду м. Запоріжжя від 25 листопада 2019 року у справі № 335/8518/17 2-к/335/5/2019. URL: http://reyestr.court.gov.ua/Review/86231507. 
Незайвим було б уніфікувати процесуальне законодавство із законодавством про виконавче провадження, виокремивши в Законі України «Про виконавче провадження» окремий розділ, присвячений примусовому виконанню рішень іноземних судів. Такий підхід буде лише сприятиме дотриманню чіткої процедури з виконання рішень даної категорії з боку як органів примусового виконання, так і сторін виконавчого провадження, а також дасть змогу уникнути правових прогалин у національному законодавстві.

\section{АНОТАЦІЯ}

Стаття присвячена теоретичним і практичним питанням визнання та виконання рішень іноземних судів, особливостям розгляду судами України клопотань іноземних осіб про надання дозволу на їх примусове виконання. Наведено погляди науковців щодо визначення понять «визнання» та «виконання» таких рішень. Викладено розуміння цих понять, яке полягає в тому, що під «визнанням» рішення іноземного суду необхідно розуміти поширення законної сили рішення іноземного суду на територію України в порядку, установленому законодавством України, а під «виконанням» рішення іноземного суду - застосування всіх засобів щодо примусового виконання рішення іноземного суду в порядку, визначеному законодавством держави, на території якої воно виконується. Доведено, що поняття «визнання» та «виконання» рішення іноземного суду є взаємопов'язаними, оскільки визнання іноземного судового рішення $є$ правовою підставою для його звернення до примусового виконання на території України.

Виокремлено основні процедурні моменти визнання й подальшого примусового виконання рішень іноземних судів. Акцентовано увагу на дотриманні іноземною особою форми та змісту клопотання про надання дозволу на примусове виконання рішення іноземного суду. Використано практичні приклади судової практики національних судів. Зроблено висновок про необхідність удосконалення нормативного регулювання процедури виконання рішень даної категорії.

\section{ЛІТЕРАТУРА}

1. Богуславский М.М. Международное частное право: учебник. Москва, 2004. 400 с.

2. Конвенція про визнання та приведення до виконання іноземних арбітражних рішень від 10 червня 1958 року. URL: https://zakon.rada.gov.ua/ laws/show/995_070. 
3. Конвенція про правову допомогу і правові відносини у цивільних, сімейних і кримінальних справах 1993 року, ратифікована 10 листопада 1994 Верховною Радою України. URL: https://zakon.rada.gov.ua/laws/ show/997_009.

4. Конституція України : Закон України від 28 червня 1996 року. URL: https://zakon.rada.gov.ua/laws/show/254к/96-вр.

5. Лев М.О. До питання розуміння визнання іноземного судового рішення в міжнародному приватному праві. Часопис Київського університету права. 2013 № 2.С. 379-383.

6. Постанова Київського апеляційного суду від 3 грудня 2019 року у справі № 372/2267/19. URL: http://reyestr.court.gov.ua/Review/86203863.

7. Про визнання та виконання в Україні рішень іноземних судів : Закон України від 29 листопада 2001 року № 2860-III. URL: https://zakon.rada.gov.ua/laws/show/2860-14.

8. Про виконавче провадження : Закон України від 2 червня 2016 року 1404-VII. URL: https://zakon.rada.gov.ua/laws/show/1404-19.

9. Про затвердження Інструкції про порядок виконання міжнародних договорів $з$ питань надання правової допомоги в цивільних справах щодо вручення документів, отримання доказів та визнання і виконання судових рішень: Наказ Міністерства юстиції України від 27 червня 2008 року № 1092/5/54. URL: https://zakon.rada.gov.ua/laws/show/z0573-08.

10. Про міжнародне приватне право: Закон України від 23 червня 2005 року № 2709-IV. URL: https://zakon.rada.gov.ua/laws/show/2709-15.

11. Про міжнародний комерційний арбітраж : Закон України від 24 лютого 1994 року № 4002-XII. URL: https://zakon.rada.gov.ua/laws/show/4002-12.

12. Про практику розгляду судами клопотань про визнання виконання рішень іноземних судів та арбітражі іпро скасування рішень, постановлених у порядку міжнародного комерційного арбітражу на території України : Постанова Пленуму Верховного Суду України від 24 грудня 1999 року № 12. URL: https://zakon.rada.gov.ua/laws/show/v0012700-99.

13. Угода про порядок вирішення спорів, пов'язаних із здійсненням господарської діяльності, від 19 грудня 1992 року. URL: https://zakon.rada. gov.ua/laws/show/997_076.

14. Ухвала Драбівського районного суду Черкаської області від 4 листопада 2019 року у справі № 692/850/19. URL: http://reyestr.court.gov.ua/ Review/85443692.

15. Ухвала Жовтневого районного суду м. Харкова від 4 листопада 2019 року у справі № 639/7923/19. [URL: http://reyestr.court.gov.ua/ Review/85697736.

16. Ухвала Луцького міськрайонного суду від 7 жовтня 2019 року у справі № 161/11010/19. URL: http://reyestr.court.gov.ua/Review/85620463. 
17. Ухвала Мукачівського міськрайонного суду від 6 грудня 2019 року у справі № 2-к/303/1/19. URL: http://reyestr.court.gov.ua/Review/86157182.

18. Ухвала Орджонікідзевського районного суду м. Запоріжжя від 25 листопада 2019 року у справі № 335/8518/17 2-к/335/5/2019. URL: http://reyestr.court.gov.ua/Review/86231507.

19. Ухвала Фастівського міськрайонного суду Київської області від 8 листопада 2019 року у справі № 2-к/381/1/19. URL: http://reyestr.court.gov.ua/Review/85510320.29.

20. Ухвала Херсонського міського суду Херсонської області від 05.12.2019 у справі № 766/10821/19. URL: http://reyestr.court.gov.ua/ Review/86137588.

21. Фортуна Т.Я. Поняття та правова природа визнання та виконання рішень іноземних судів в Україні. Адвокат. 2011. № 7 (130).С. 43.

22. Цивільний кодекс України : Закон України від 16 січня 2003 року. URL: https://zakon.rada.gov.ua/laws/show/435-15.

23. Цивільний процесуальний кодекс України : Закон України від 18 березня 2004 року № 1618-IV. URL: https://zakon.rada.gov.ua/laws/ show/1618-15.

\section{Information about author: Belikova S. O., Ph.D.,} Head of the Department for the Training of Prosecutors in the Representation of State Interests in the Court National Academy of Prosecution of Ukraine 81-b, Yuri Ilyenko, Kyiv, Ukraine

DOI https://doi.org/10.30525/978-9934-588-43-3/1.19 